\title{
First report of Pseudoidium aff. neolycopersici in Indonesia
}

\author{
Iman Hidayat • Jamjan Meeboon • Susumu Takamatsu
}

Received: 12 March 2014 / Accepted: 11 July 2014 / Published online: 25 July 2014

(C) Australasian Plant Pathology Society Inc. 2014

\begin{abstract}
Tamarillo was found to be heavily infested with powdery mildew in Bali, February 2012. The cause of the disease, Pseudoidium aff. neolycopersici, was characterised based on the morphology and molecular phylogenetic analysis of the internal transcribed spacer sequence. This is the first report of $P$. aff. neolycopersici on tamarillo in Indonesia.
\end{abstract}

Keywords Plant pathogen · Powdery mildew · Tamarillo · Taxonomy $\cdot$ Indonesia

Solanum betaceum (syn. Cyphomandra betacea) (English: Tamarillo or Tree Tomato, Indonesian: Terung Belanda) is a small tree belonging to the family Solanaceae, originating from South America. The tamarillo tree is 3-7.5 $\mathrm{m}$ tall, leaves ovate, heart-shaped at the base and pointed at the apex, bearing egg-shaped berries with pointed ends that are arranged in clusters near the young shoots. In Indonesia, tamarillo is planted as a backyard venture for its edible berries. Tamarillo was probably introduced to Indonesia by the Netherlands in 1941. Australia and New Zealand have been recognised as exporting countries of tamarillo fruit (Morton 1987).

\section{Hidayat $(\triangle)$}

Research Center for Biology, Indonesian Institute of Sciences (LIPI), Jl. Raya Jakarta-Bogor KM46, Cibinong 16911,

West Java, Indonesia

e-mail: imanhidayat@yahoo.com

\section{J. Meeboon}

Ministry of Agriculture and Cooperatives,

50 Phaholyothin Rd., Ladyao, Chatuchack, Bangkok, Thailand

e-mail: jamjanm@yahoo.com

\section{S. Takamatsu}

Faculty of Bioresources, Mie University,

1515 Kamihama, Tsu 514-8507, Japan

e-mail: takamatu@bio.mie-u.ac.jp
Powdery mildew (PM), causing serious defoliation, is recognised as a principal disease infecting tamarillo at locations where the plant is grown. Other fungi causing disease on tamarillo include Sclerotinia sclerotiorum and Ascochyta sp. (Morton 1987). During the survey of phytopathogenic fungi in February 2012, we found high infestation of PM on the leaves of tamarillo in Bedugul Botanic Garden and its surrounding area (Bali). The leaves were colonised by amphigenous, grayish-white, irregular and circular patches of mycelia (Fig. 1). Conidia were abundant on both sides of the leaf surface. The infected leaves became yellow and showed necrotic spots or blight. Heavy infection was mainly found on older leaves, and no PM mycelia or conidia were found on the berries.

Morphological observation was conducted following the method described by Meeboon et al. (2013). Anamorph (Fig. 1) - mycelium amphigenous, effuse, white; hyphae 4 $7 \mu \mathrm{m}$ wide, hyaline, thin-walled; hyphal appressoria in opposite pairs, occasionally solitary, moderately lobed, 3-7 $\mu \mathrm{m}$ diam.; conidiophores erect from top of mother cell, $\left(50^{-}\right) 54$ $-95(-114) \times\left(6^{-}\right) 7.5-10(-11) \mu \mathrm{m}$, foot-cells subcylindrical, straight to often curved at the base, $\left(20^{-}\right) 22-40(-45) \times(6$ $-) 7.5-10(-11) \mu \mathrm{m}$, followed by $1-2$ shorter cells or a cell about as long as the foot-cell or even longer, forming conidia singly or in short false chains; conidia ellipsoid-ovoid, subcylindrical, (25.5-)28-35(-38) $\times(10.5-) 12-17(-17.5)$ $\mu \mathrm{m}$; germ tubes simple, short, straight, cylindrical. Teleomorph was not observed.

Genomic DNA was extracted from the PM colony on the leaf using the chelex method as described in Hirata and Takamatsu (1996). Specimens were deposited at the Mie University Mycological Herbarium (MUMH), Japan (MUMH5562). Molecular phylogenetic analysis based on the sequence from the ITS rDNA region was conducted to identify the PM on tamarillo to species level. This region was amplified using primer pairs of ITS5 (White et al. 1990) and p3 (Kusaba 
Fig. 1 Pseudoidium aff. neolycopersici. (a) symptoms on leaf (arrows); (b) conidium with germination tube (arrow); (c) hyphal appressoria (arrow); (d) conidiophores and conidia. $\operatorname{Bars}=15 \mu \mathrm{m}(\mathbf{b}, \mathbf{c})$ and $30 \mu \mathrm{m}(\mathbf{d})$
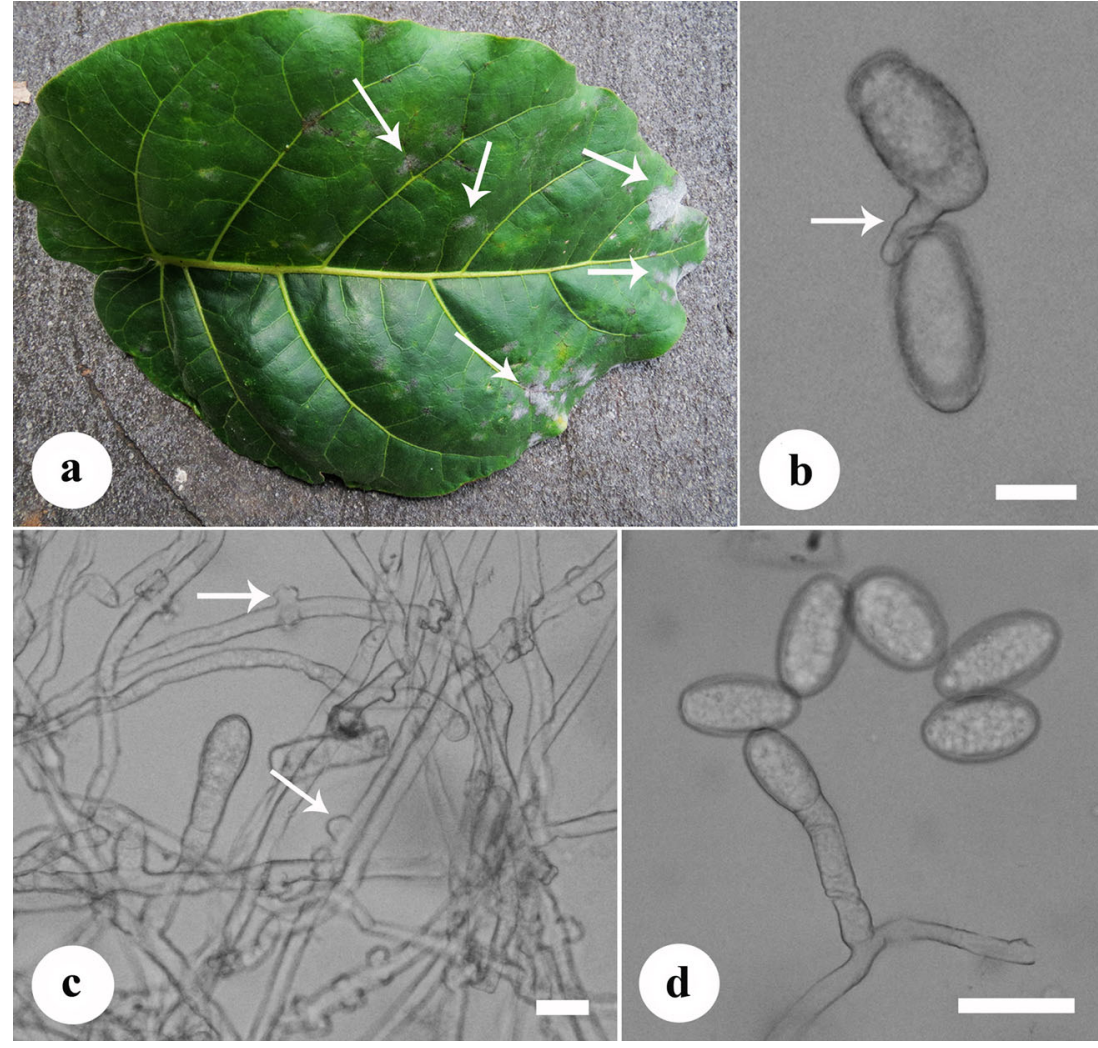

Fig. 2 Phylogenetic tree inferred from ITS rDNA sequence showed the placement of Pseudoidium aff. neolycopersici (AB911568) among PM species. The tree is rooted with the outgroup sequence of Parauncinula septata (AB183533). Branch lengths are indicated (scale bar). Bootstrap values $\geq 50 \%$ are shown above internodes

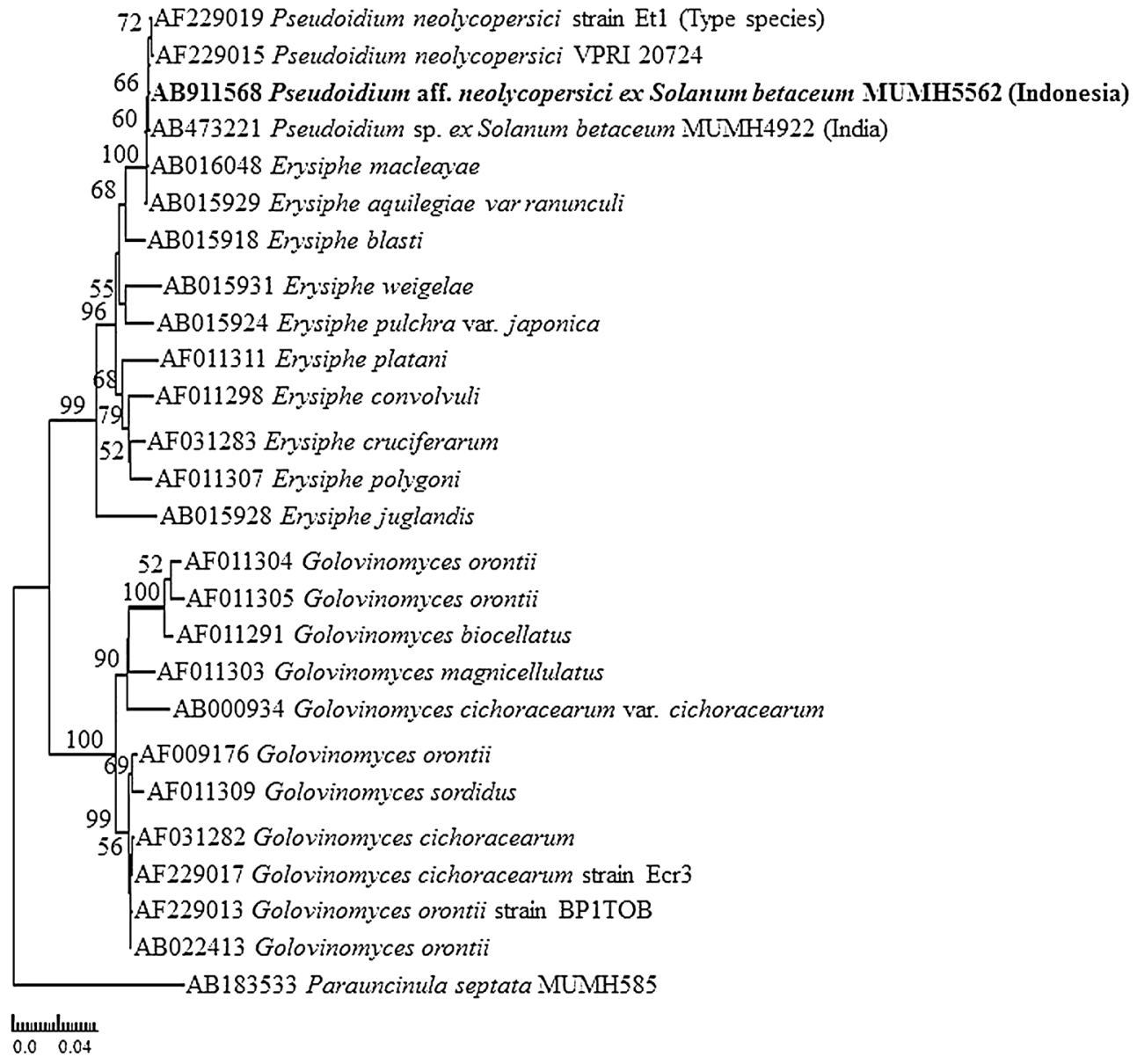


and Tsuge 1995) for the first amplification, and PM-specific primer sets ITS5/PM6 and PM5/p3 for the second amplification (Takamatsu and Kano 2001). The primer pair of ITS1-ITS4 (White et al. 1990) was used for sequencing. Raw sequences were trimmed and assembled using ChromasPro 1.7.6 (http:// technelysium.com.au/). The new DNA sequence was deposited to the GenBank/EMBL/DDBJ databases under the accession number AB911568. Multiple alignment of the new sequence with closely related PMs was conducted using MUSCLE (Multiple Sequence Comparison by Log-Expectation) implemented in MEGA (Molecular Evolutionary Genetics Analysis) version 6.0 (Tamura et al. 2013). Phylogenetic analysis was conducted using the Neighbour-Joining (NJ) method in MEGA 6.0. All parameters were set as default. The strength of the internal branches of the phylogenetic tree was tested with bootstrap analysis using 1,000 replications.

Pairwise sequence alignment showed that the ITS sequence of the PMs on tamarillo from Indonesia and India were identical (data not shown). In the phylogenetic tree, both sequences nested together with Pseudoidium neolycopersici on Solanum lycopersicum (Solanaceae) with $66 \%$ bootstrap support (BS). Sequence alignment of the PM on tamarillo with the holotype of P. neolycopersici strain Et1 (AF229019) showed only one base difference (data not shown). This clade nested together with E. aquilegiae var. ranunculi (AB015929) and E. macleayae (AB016048) to form a monophyletic clade with $100 \%$ BS. Erysiphe aquilegiae var. ranunculi (anamorph: Oidium clematidis) was reported worldwide on various genera belonging to the family Ranunculaceae and on Catharanthus roseus (Apocynaceae), while E. macleayae was only found in temperate regions (China, Japan, Germany, and Switzerland) on Macleaya cordata and Papaver cambricum (syn.: Meconopsis cambric) (Papaveraceae) (Braun and Cook 2012). According to the Systematic Mycology and Microbiology Laboratory Fungus-Host Database (http://nt.ars-grin.gov/ fungaldatabases/fungushost/FungusHost.cfm), four species of PMs were reported on Cyphomandra. These include $P$. neolycopersici (Pseudonym: O. lycopersici) on C. betacea from India; Golovinomyces cichoracearum (Syn. E. cichoracearum) on $C$. betacea and $C$. fragrans from France, Australia and New Zealand; G. orontii (syn.: E. orontii) on the same hosts as G. cichoracearum from New Zealand; and Leveillula taurica (Anamorph: Oidiopsis sicula) on $C$. betacea from Guinea (Africa). The current PM on S. betaceum found in Indonesia apparently resembles the morphological characteristics of Pseudoidium (teleomorph: Erysiphe) due to its conidia formed singly or in short false chains with solitary (occasionally in opposite pairs) and moderately lobed hyphal appressoria (Braun and Cook 2012).

The PMs on tamarillo from India were determined by Sharma et al. (2011) and Baiswar et al. $(2009,2013)$ as O. lycopersici and Oidium sp. [neolycopersici], respectively. However, following the recent taxonomic status of both names (Braun and Cook 2012), they are now recognised as $P$. neolycopersici. This study clearly showed a close relationship between $P$. neolycopersici and the PM on tamarillo, although with a somewhat low bootstrap support (Fig. 2). It is possible that both PMs diverged recently, and is in the process of speciation. However, evidence is limited to prove that both PMs belong to different species, therefore, we named the PM on tamarillo as P. aff. neolycopersici. Braun (2012) discussed the taxonomical status of the PM on tamarillo. Although this fungus was morphologically indistinguishable from $P$. neolycopersici, and was unable to infect tomato and several species of Solanum, the taxonomical status of this fungus is still unclear (Braun 2012). Molecular phylogenetic analysis of $28 \mathrm{~S}$ and IGS (intergenic spacer) rDNA regions may clarify the taxonomical status of the PM on tamarillo (Glawe 2008). This is the first report of $P$. aff. neolycopersici on tamarillo in Indonesia.

Acknowledgments The authors gratefully thank Agung Kurniawan from the Bedugul Botanic Garden for specimen collection.

\section{References}

Baiswar P, Braun U, Chandra S, Ngachan SV (2009) First report of an Oidium sp. [neolycopersici] on Solanum betaceum in India. Australas Plant Dis Notes 4:32-33

Baiswar P, Ngachan SV, Braun U, Takamatsu S, Chandra S, Harada M (2013) Molecular characterization of Oidium sp. on Solanum betaceum in India. Environ Ecol 31:1364-1367

Braun U (2012) The impacts of the discontinuation of dual nomenclature of pleomorphic fungi: the trivial facts, problems, and strategies. IMA Fungus 3:81-86

Braun U, Cook RTA (2012) Taxonomic manual of the Erysiphales (powdery mildews). CBS Biodiversity Series No.11. CBS, Utrecht

Glawe DA (2008) The powdery mildews: a review of the world's most familiar (yet poorly known) plant pathogens. Annu Rev Phytopathol $46: 27-51$

Hirata T, Takamatsu S (1996) Nucleotide diversity of rDNA internal transcribed spacers extracted from conidia and cleistothecia of several powdery mildew fungi (in Japanese). Mycoscience 37:283-288

Kusaba M, Tsuge T (1995) Phylogeny of Alternaria fungi known to produce host-specific toxins on the basis of variation in internal transcribed spacers of ribosomal DNA. Curr Genet 28:491-498

Meeboon J, Hidayat I, Takamatsu S (2013) Setoidium castanopsidis, a new species of anamorphic Cystotheca (Ascomycota, Erysiphales) from Indonesia. Mycoscience 54:274-278

Morton JF (1987) Fruits of warm climates. Creative Resource Systems, Inc., Winterville

Sharma PK, Ahmad N, Roy SS (2011) First report of powdery mildew of tree tomato from Manipur. Indian J Mycol Pl Pathol 41:652

Takamatsu S, Kano Y (2001) PCR primers useful for nucleotide sequences of rDNA of the powdery mildew fungi. Mycoscience 42:135-139

Tamura K, Stecher G, Peterson D, Filipski A, Kumar S (2013) MEGA6: molecular evolutionary genetics analysis version 6.0. Mol Biol Evol 30:2725-2729

White TJ, Bruns TD, Lee SB, Taylor JW (1990) Amplification and direct sequencing of fungal ribosomal RNA genes for phylogenetics. In: Innis MA, Gelfand DH, Sninsky JJ, White TJ (eds) In 'PCR protocols: a guide to methods and applications'. Academic, San Diego, pp 315-322 